\title{
Concepts towards a novel integrated assessment methodology of urban water reuse
}

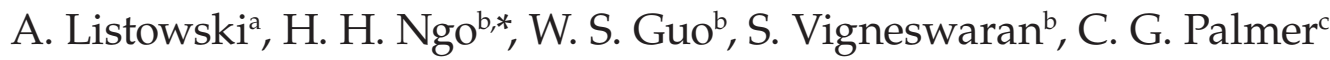 \\ aSydney Olympic Park Authority, 7 Figtree Drive, Sydney, NSW 2127, Australia \\ ${ }^{b}$ School of Civil and Environmental Engineering, University of Technology Sydney, PO Box 123, \\ Broadway, NSW 2007, Australia \\ Tel.+61 (2) 95141693; Fax.+61(2) 95142633; email: h.ngo@uts.edu.au \\ 'Institute of Water and Environmental Resource and Management, University of Technology Sydney, Broadway, NSW 2007, Australia
}

Received 24 March 2009; Accepted 31 August 2009

\section{ABSTRACT}

Traditional supplies of large volumes of water and wastewater disposal technologies have offered a linear solution, thus intensifying environmental stress. In addition, provision of urban infrastructure especially any major augmentations are often the impractical or economically prohibitive. Urban water cycle should be viewed as an interactive and coordinated approach involving:

- Available water resources,

- Appropriate treatment technology producing fit for purpose water quality, and

- Ascertaining long term balance between environmental, social and economic issues.

Implementation of integrated water reuse scheme requires major paradigm shift within a number of technical (science, technology and knowledge) and non-technical (socio-cultural, economic, environment) dimensions. There are number of questions that arise from this scenario:

- How to make decisions regarding selection, design, implementation and operation of any recycling scheme?

- What knowledge is necessary to improve decision-making process?

- How to assess and compare performance of the scheme?

- What are the parameters for uniform evaluation process?

The aim of this paper is to introduce a new concept for integrated assessment methodology that can be applied for urban water reuse schemes. The conceptual assessment methodology relies on decision that treatment technology represents a leading theme and is supported by selection of socio-economic and environmental factors, thus enabling holistic evaluation and quantification of the outcomes.

Keywords: Urban water reuse; Integrated assessment framework and methodology

\section{Introduction}

In 2003 Prime Minister's Science, Engineering and Innovation Council (PMSEIC) confirmed recycled water

${ }^{*}$ Corresponding author. as one of the main sources for providing reliable water supplies to our cities. In facilitating these changes, it would be important to develop a rigorous framework that would enable comparison of a wide range of technologies, management options; economic, financial, health, environmental and social factors of the various 
urban water cycle schemes on a "whole of lifecycle" basis [1].

Assessment techniques of the wastewater treatment and recycling vary considerably and so far, there is not yet a single definitive procedure for conducting integrated appraisal, involving technology and a sustainability structure of social, economic and environmental functions. The field of modern water management characterized by integration of water resources, treatment and reuse, requires application of a cross-disciplinary analysis, research and technology that play dominant role in selection of appropriate treatment processes and performance standards.

At present appraisal of the wastewater treatment and reuse scheme is usually considered as a technological selection, assessed on the basis of economic market transactions. Environmental and social impacts play important role, however they are performed as a routine administrative functions to satisfy required development approval process.

During operation phase, a limited attention is given to collection of a valuable data (beyond mandatory statutory requirements) that could allow verification of project assumptions and scheme performance. In this situation any definitive statements regarding performance or comparison between various water reclamation and reuse schemes are difficult and questionable, due to:

- Lack of uniform assessment and verification technique and tools

- Unavailability of essential operational data and performance information

- Monitoring data is narrowed to essential representative parameters eg, water quality, quantity, operating costs, compliance with the regulatory guidelines, etc

- Inconclusive outcome resulting from the above

This problem is further exacerbated by the fact that there is no comprehensive framework, a formal structure that would guide and enable assessment and performance verification process.

The main target of this research is on development of assessment framework and methodology for wastewater treatment and reuse technology, based on the integrated water cycle concept with outcomes on the decision support model. The framework considers technology criteria that are incorporated into urban water cycle operations socioeconomic and environmental conditions. All the above is aimed at the development of a universal assessment model detailing fundamental design and operating principles. The strategic assessment framework is intended to encourage sustainable urban water reuse concepts through scientific analysis. Integrated assessment is a new generation of sustainability assessment.
It comprises a 'leading theme' and contributory subjects that are important in the assessment process.

In this context, technology is selected as a leading theme because it has profound influence on entire concept of wastewater treatment, reuse and sustainability. It plays crucial role in complete transformation process of urban wastewater and stormwater, through application of science, physical, chemical and biological processes.

Urban wastewater treatment and reuse practices pose considerable challenges for technology assessment because it contributes to opinion and decision forming process. Progressively conventional technologies are being transformed to systems deploying a wide range of disciplines and complex components. Also due to environmental and socio-economic pressures there is a shift of focus towards technologies that support balanced objectives of sustainable development. Considerations of a long-term perspective, dealing with the integration problem, complex cause/effect relations and the inclusion of extra-scientific communication already have been practiced for a long time. One can therefore go back to conceptions and methodical approaches of technology assessment for sustainability assessments of technology [2].

Integration means a new entity is created and new relationships are established. Individual criteria have specific characteristics and specific dynamics, but in combination with each other they act in a different way. Methodological integration involving environmental, economic, social factors is the key.

\section{The framework}

In the past decades the trend in urban water services began to shift from traditional supply/demand scenario to more sophisticated integrated approaches, stimulated by increased public concerns, high costs and growing environmental awareness.

The urban water reuse represents shift away from traditional supply/demand scenario to more balanced integrated water management approaches. Naturally we must approach this new concept differently and applying usual planning and evaluation processes will not constitute any progress. Complexity and challenges arising from this shift are mainly attributed to the fact that, besides addressing physical issues associated with drinking water supply and wastewater disposal we must actually incorporate more sophisticated treatment technologies, new water product and additional social, economic and environmental objectives. As expected, the decision-making philosophy and process must also be transformed to reflect on the holistic systems approach. 
Objectives, drivers and motives behind integrated urban water reuse, must clearly complement fundamentals of sustainability framework by incorporating the following principles:

- Reduction of use of natural water resources

- Reduction in wastewater generation and disposal to environment

- Reduction in energy consumption and emissions

- Improved efficiency of urban water system

- Improved urban environment quality

Fig. 1 illustrates how integrated assessment framework architecture for this study was structured to ensure relativity between technology and sustainability issues, by tying together all necessary discrete components into consistent and useful application. The central object of this framework is technology playing crucial role and a main theme of the assessment. Technology determines wastewater treatment process and affects environmental, social and economic outcomes. Similarly, sustainability criteria have stimulating effect on technology research, development and performance.

There are two main aspects of the assessment structure:

- Defining the framework and principles (higher level), and

- Defining the methodology process (lower level) that is closely linked with the principles and pre-determined set of evaluation criteria.

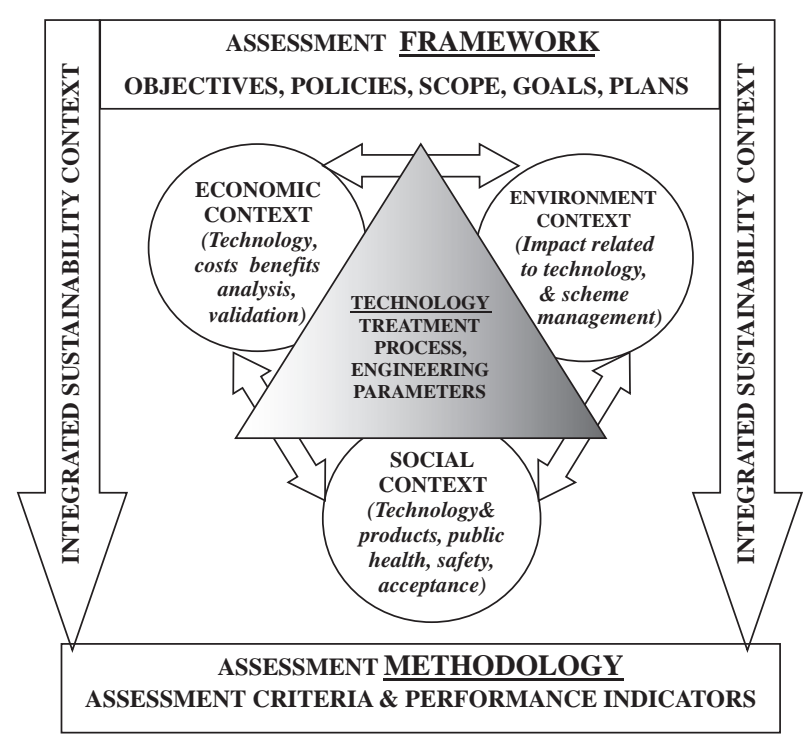

Fig. 1. Assessment structure for Integrated Water Reuse Technology.
The assessment framework is focusing on the principles of integrated urban water management cycle and includes the following 5 elements:

Technology Wastewater treatment processes and recycled water scheme operation contain cumulative engineering and scientific knowledge that is critical for making any determination of its functionality, performance, efficiency, compliance and standards. Technology application activates unavoidable consequences but often hinders holistic assessment. It remains a dominant factor in characterisation of wastewater treatment and reuse processes and is influenced by continuously increasing expectations in water conservation, water quality, usage, waste minimisation, cost, effective and stable operation, etc mainly driven by the following issues:

- High recycled water quality requirements set by customer and regulator

- Optimal operation and high water production rates

- Motivation to achieving overall reduction in operating costs

- Consistency, reliability and efficiency of the treatment process

- Security of supply of raw water sources and confidence in sustained recycled water demand

- Ongoing improvements, innovation, optimisation and adaptation programs.

The main focus of strategic technology assessment is to measure its performance and to determine whether the treatment process accomplished required standards. The literature review on this subject confirmed, that there are no scientific agreements on what are the best analytical methods, criteria and indicators to apply. The selection and relevance of appropriate tools are undoubtedly decisive for the outcome of any analysis and thus for influencing the decision-making process. Technology is the central feature of the treatment therefore specific performance characteristics such as assessment criteria, performance indicators and quantitative index values have been identified as essential steps. The logical sequence of assessment process consists of the following elements:

- Identification of specific assessment criteria.

- Selection of performance indicators for each criterion to enable data input, calculations and measurable output.

- Determination of consistent measurement method, and quantitative index value to support the indicators.

Fig. 2 below illustrates a dynamic representation of the typical wastewater treatment and reuse process. It simulates system operation on a continuous basis and it consists of the three major components:

- input $=$ sewer hydrology and process components influencing technology selection 


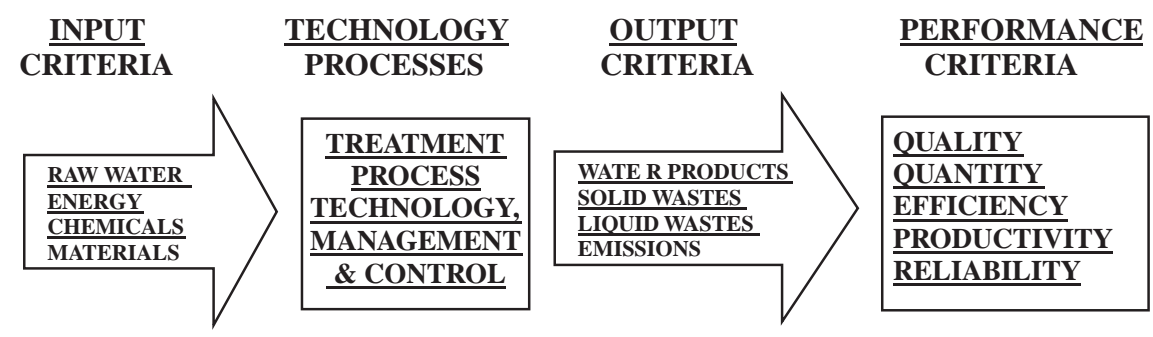

Fig. 2. Model of wastewater treatment technology assessment process.

- output = products and qualities characterising treatment process capability,

- technology performance assessment comprising of

- performance indicators characterizing treatment, and

- data analysis to enable detailed performance evaluation

Technology assessment model follows predetermined stages and systematic grouping of activities leading to analysis of the treatment process. All physical, chemical and biological treatment processes exhibit some degree of performance variability. This is due to unpredictable nature of the water source, process operation, quality requirements, maintenance, climatic conditions, etc.

It is not necessary that all technologies are studied and included in this assessment, but it is important to be aware of the interdependencies and context in which the assessment framework is set.

Environmental Context Wastewater reclamation and reuse scheme have a long term impact on natural water sources, energy, the land, the environment receiving recycled water by-products, emissions, pollutants, etc. The fundamental environmental criterion for wastewater reclamation and reuse could be summarised in the broad principles:

- conservation of water resources,

- reduction in pollution of receiving waters and

- minimisation of adverse environmental impact.

Water integration studies have focused on reducing the amount of water used on the assumption that environmental impact is reduced through efficient water reuse. This study addresses the question on integration of urban water resources and environmental impact associated with implementation of water reclamation and reuse. This could potentially introduce an additional impact; however an important challenge is to demonstrate that there should be a balance between competing sustainability objectives and tangible offsets that would create positive outcome.

Clean Production (CP) approach is aligned with wastewater reclamation and reuse as a supporting concept for determination of the environmental impacts due to waste reduction, reuse or recycling techniques. Adaptation and application of the currently applied environmental assessment methods including; Life Cycle Assessment (LCA) and Material Flow Analysis (MFA) coupled with relevant assessment criteria satisfies objectives of the integrated assessment framework [3].

Economic Context Performance and costs analysis are essential foundation for successful implementation and continued operation of the water reuse scheme. The economy is the best way to realistically analyse and compare performance and to confirm, from the selection of combinations of technologies and processes, the scheme that would provide required levels of treatment, desired recycled water quality at the total unit costs [4].

The economic value of the recycled water and pricing are not equitable at the present and should be established based on the following objectives:

- Economic efficiency

- Financial viability, and

- Social equity

Efficient and effective water pricing systems should provide incentives for economical water use and for water quality protection. They should also generate funds for necessary infrastructure development and expansion, and provide a good basis for ensuring that water services can be provided to customers at an affordable price. Development of uniform cost categories for treatment technologies assuming operating regime, establishing technically justified operating parameters, production rates, operating and maintenance expenditure would be essential for assessment and comparison between various projects. Land and construction costs of facilities shall be considered as sunk cost and will not be included in the cost analysis.

Social Context While recycled water is considered a commodity with defined economic value and a logical solution to the growing pressure on our water resources, its implementation faces number of social obstacles including; health and hygienic risk, poor understanding of the environmental value, ambiguous water cost/price relations, ineffective communication and poor community information, limited trust in water authority's management and technology. Currently, no formal standard framework has been established to build successful and ethical public involvement programs for water reuse [5]. 
To protect public health and the environment, it is necessary to recognize some specific factors that influence public perceptions and acceptance of urban recycled water use including the following:

- Origin of raw water sources and constituents of concern

- Treatment technology,

- Recycled Water quality standards,

- Health risk and exposure

- Environment impact

- Economic drivers and cost benefits,

- Operations. management and necessary contingency provisions

A range of socio-economic and environmental factors will continue to influence future decisions, behaviors and consequential impacts, influences water reclamation technologies. A system based assessment framework recognises these interdependencies in the real and practical context.

Integrated Sustainability Context The final element of the framework involves integration and realignment of technical, environmental, economic and social aspects by applying tangible focus on the water reuse technology as a main theme and take full advantage of sustainable development approaches, clean production principles, conservation of natural resources and achieving longterm economic growth. Integrated assessment could help integrate, reconcile, organize, and communicate knowledge across the above domains.

Existing assessment models are often fragmented in terms of reconciling the different domain perspectives in evaluation, do not provide comprehensive characterization of the technology context and are not sensitive to the socio-economic, institutional and environmental context within which performance is assessed [6,7]. Significantly, no clear systemic frameworks have emerged to guide continuous development of urban water reuse. The framework for assessment of a wastewater treatment and reuse technology is recognising that the development and implementation of any technology would always generate environmental, economic and social effects as integrated and simultaneous processes [8].

The conceptual framework above explicitly links technology with ecosystem services, human well-being, served as a common starting point for the methodology development. Use of this conceptual framework helps to focus on selecting specific water services and also guided the analysis of interactions and trade-offs among possible future scenarios.

\section{Assessment methodology}

While framework is collating all necessary components, assessment methodology is seeking to supply all necessary tools to perform quantitative and qualitative evaluation process. It provides measures and principles that are necessary for evaluation. The methodology process includes the following tasks:

- Evaluate performance of treatment technologies using predetermined set of assessment criteria and performance indicators

- Provide objective ranking and benchmarking that are aligned with world best practice

- Generate high quality performance data that will be used as a mechanism by which the performance can be measured, verified or compared.

- Support decision makers in making informed selection of environmental technologies

The overall aim of assessment methodology is to establish mechanisms and measures that can be applied to the evaluation process and provide coherent approach for integrated assessment. The specific objectives of this process are:

- To establish a set of criteria and indicators that characterise and compare performance of wastewater treatment and reuse technologies

- To select relevant sustainability criteria that interrelate to technology performance including impact, risk and benefits

Assessment methodology is a means to identifying and comparing possible technology options and will ensure that the importance of all economic, social and environmental considerations are clearly understood, directly incorporated the values of relevant stakeholders into the decision and achieve the best possible outcome for all stakeholders [9].

Fig. 3 below outlines an important feature of this assessment methodology is that it reduces complexity and adds value by summarization, synthesis, and sorting widely accepted elements. Levels of certainty on the findings are often expressed, either qualitatively or quantitatively. Given widely varying environmental, and socioeconomic circumstances, it was necessary to harmonise technology, with these aspects, adapt and accommodate varying circumstances and design specific process, supported by defined multi-disciplinary models. It is apparent that there are three main stages of the assessment process are:

- Mass balance analysis and definition of process requirements,

- Determination of performance assessment mechanisms, and

- Evaluation and system performance verification.

Assessment Criteria involve identification of all necessary technical, environmental, social and economic assessment conditions that characterise the wastewater treatment and reuse processes. Due to complexity and 


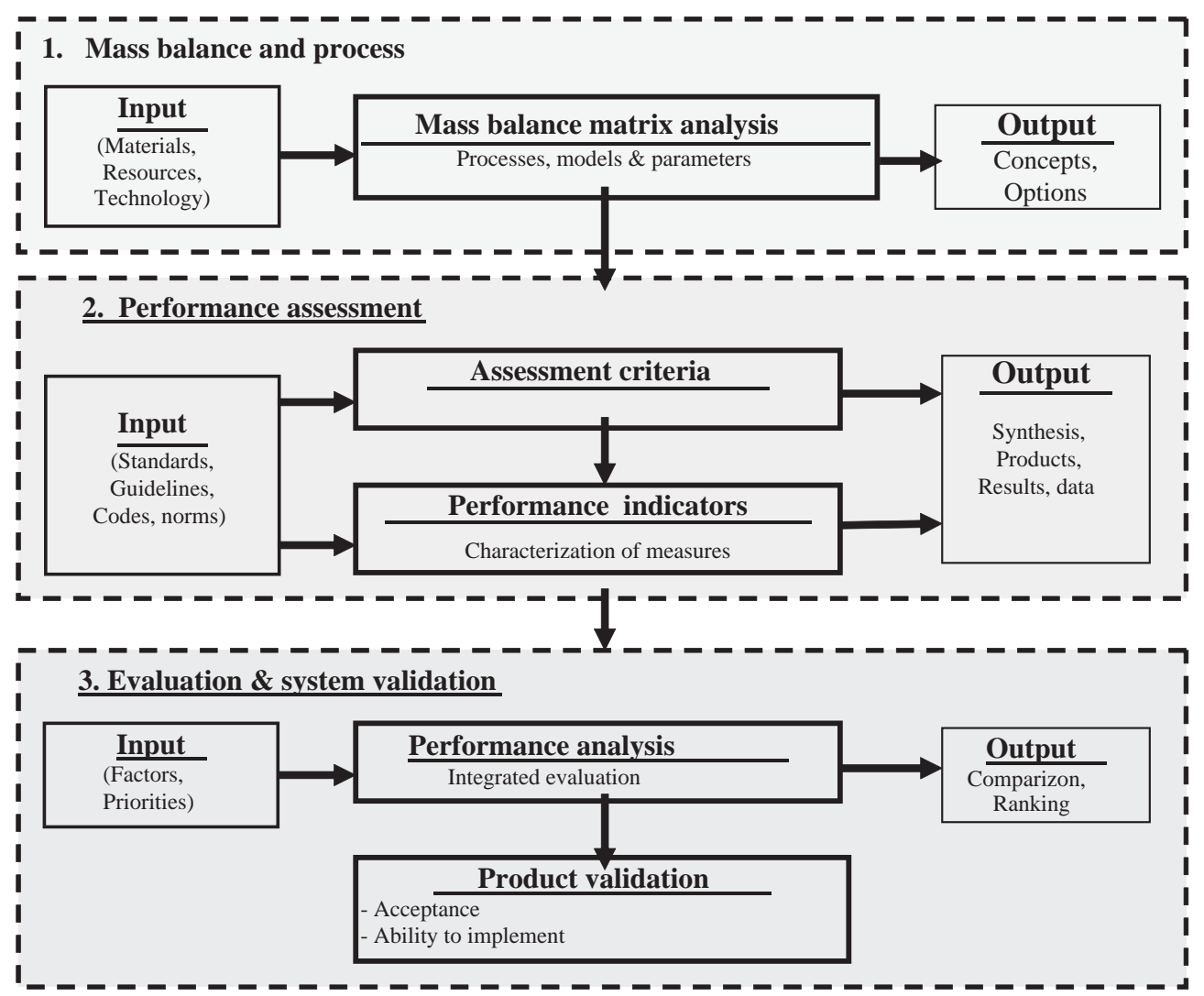

Fig. 3. Process in consideration of an integrated assessment methodology.

integrated nature of water reuse the most appropriate is a Multi Criteria Assessment (MCA) technique which includes quantifiable elements such as:

- Quality,

- Quantity,

- Productivity, and

- Efficiency and reliability.

Performance indicators (PIs) are one of many tools to help answer the question: How and what needs to be measured, in order to quantify results and achievements? PI are defined as a set of quantifiable values including; parameters, elements, rates, calculations, limits, factors, etc. PI are expressed as quantitative indicators and be presented as a numbers of tangible benefits-products processes including; quality, quantity, productivity, efficiency, effectiveness, etc.

The performance indicator set spans the following areas:

- Wastewater influent physical and bio-chemical factors that affect the process

- Pretreatment and chemical dosing

- Secondary biological treatment process

- Advanced/tertiary treatment using filtration techniques (MF, UF, RO, MBR)
- Disinfection process

- Effluent water quality

- Recycled water quality

- Biosolids and side streams products

- Greenhouse gas emissions;

Performance analysis Evaluation and ranking synthesizes outcome of all the above steps as a model of an integrated assessment methodology. This model would identify critical issues, future opportunities and make any necessary recommendations. It would be essential to assist public and policy makers in making informed, value-based decisions.

\section{Case study-Summary}

WRAMS assessment framework and methodology has been considered as a two step process. Initial step involves comprehensive characterization and performance assessment of treatment technology (this study). Subsequently a comprehensive analysis of the scheme would be performed and it would incorporate sustainability factors; environmental, economic and social.

This case study will demonstrate how new concept framework and methodology could apply to a full-scale operation of the Water Reclamation and Reuse Scheme (WRAMS) at Sydney Olympic Park. 
WRAMS commenced its operation in July 2000 and hence it was the first urban reuse scheme in Australia. It exemplifies of how innovative approaches to integrated water cycle could be employed to accomplish a complete system for water management of a discrete area, encompassing wastewater collection and treatment, stormwater harvesting, improving quality of receiving waters, meeting continuously all non-potable water needs, managing dual - potable and recycled water supply infrastructure.

WRAMS has capability to supply high quality recycled water to all sporting venues, commercial facilities and parklands of Sydney Olympic Park and the neighbouring residential suburb of Newington. Current applications include:

- Toilet and urinal flushing;

- Irrigation of parklands and gardens;

- Irrigation of vegetable gardens;

- Fountains and water features;

- Playing fields;

- Fire fighting;

- Construction;

- Wash down and dust suppression;

- Clothes washing (supply to washing machine only)

- Swimming pool filters backwash

- Commercial air conditioning water cooling towers

Performance results of this scheme clearly complement fundamentals of sustainability framework including:

- Conservation of natural water resources

- Reduction in wastewater production and environmental pollution

- Improved efficiency and productivity of urban water system

- Beneficial water reuse offsetting additional energy resources consumption

The Water Reclamation and Management Scheme (WRAMS) is design to receive and treat sewage and stormwater and continuously produce high quality of recycled water. The main characteristics of WRAMS operation have been collated in the table below.

\subsection{WRAMS—quantitative assessment}

Quantitative investigation is a fundamental step in the assessment process. It defines the scope, variables, and produces foundation for further analysis. Moreover, quantitative approach offers an explicit framework based on empirical data that provides a point-of-entry for further quantitative and/or qualitative analyses in both science and science-based technology. This can invoke new valuable insights that may not only stimulate further analytical thinking and investigation, but also raise relevant key issues and contribute to discussion about aspects of interdisciplinary in scientific research.
WRAMS treatment technology is characterised by a number of physical, chemical and biological parameters that could be broadly summarised and represented by the following performance indicators (Table 1):

- resources supply,

- treatment plant capacity,

- recycled water production

- by - products generation

- energy and chemicals consumption.

The quantification of the components within the treatment process could be demonstrated using a traditional water mass balance as input and output analysis. However this method alone would not satisfy objective of a comprehensive technology assessment because it would only indicate resources movement within and the process. The relationship between various technology performance indicators have been summarised in Table 2 below.

\subsection{WRAMS—qualitative assessment}

The potential contribution of qualitative research methods in wastewater treatment and reuse technology is one of the unexplored disciplines and the debate is often limited to theory or it is almost purely academic. Qualitative research inquiries focus on effort of finding practical ways to use results as a form of evidence, but not necessarily as valuable and relevant information complementing practice and contributing to better understanding of wastewater treatment and reuse technologies.

Qualitative information offers a common base for large-scale assessments across the entire spectrum of technological and scientific activities. It is a result of application of scientific analysis and is based on system knowledge, experience and value judgment (Table 3).

\subsection{WRAMS—efficiency assessment}

Efficiency is dealing with quantification of the treatment process by assessing input versus output and is intended to set appropriate outcomes and targets to achieve desired overall goals.

Efficiency of treatment technology analysis is linked with water recovery rates includes the following examples:

- volume and \% of water savings due to reuse

- volume and \% of wastewater treatment due to reuse

- infrastructure free capacity (water \& wastewater) as a result of reuse

Pollutants removal efficiency reflects on the overall removal from sequential treatment methods, refers only 
Table 1

Typical WRAMS operating parameters (WRAMS data, 2007/08).

\begin{tabular}{ll}
\hline Parameter & Rating/Value \\
\hline Sewage & Raw water resources \\
Stormwater & Availability-Yes \\
Sewage catchment area for reuse & Availability-Yes \\
Stormwater catchment area for reuse & $\sim 500$ ha \\
Stormwater storage volume (Brickpit ) & $\sim 300 \mathrm{ha}$ \\
Average annual sewage treatment volume & $\sim 300 \mathrm{ML}$ \\
Average annual stormwater treatment volume & $620 \mathrm{ML}$ \\
Average annual recycled water production & $520 \mathrm{ML}$ \\
Average annual biosolids production @4\% solids & $770 \mathrm{ML}$ \\
Average annual energy use & $3900 \mathrm{KL}$
\end{tabular}

Mf unit model 90M10C

Design capacity

Number on units

Number of modules per unit

Total number on modules

Membrane pore size

Total area per membrane module

Total area of membranes

Design flux rate

\author{
$3 \times 2.5 \mathrm{ML} /$ day \\ 3 \\ 90 \\ 270 \\ $0.2 \mu \mathrm{m}$ \\ $15 \mathrm{~m}^{2}$ \\ $4050 \mathrm{~m}^{2}$ \\ $100 \mathrm{~L} / \mathrm{m}^{2} / \mathrm{hr}$
}

Ro unit model BW30-365 FR2

Design capacity

Design system recovery

Minimum salt rejection

Design feed TDS

Maximum pressure

Design feed water capacity

Design permeate capacity

No of stages
Maximum feed SDI

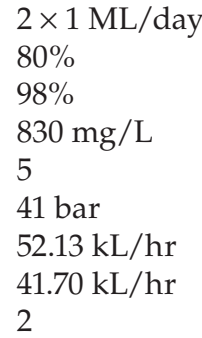

Recycled water supply

Total number of residential customers connected to RW

$\sim 10000$

Total number of commercial facilities connected to RW

100

Total are of parklands connected to RW (irrigation)

250 ha

$12 \mathrm{ML} / \mathrm{d}$

Maximum recycled water supply capacity

Maximum recycled water flow rate

Recycled water storage capacity

$260 \mathrm{~L} / \mathrm{s}$

$8 \mathrm{ML}$

$340 \mathrm{kPa}$

Recycled water pressure set point

$\sim 30 \mathrm{~km}$ to the percent destruction, degradation, conversion, or removal of the pollutants from the wastewater. Percent removal can be calculated as follows:

$P_{E F}=\frac{I_{I N F} E_{E F L}}{I_{I N F}} \times 100(\%)$
Where

$I_{I N F}=$ amount in the influent wastewater stream (entering the wastewater treatment or at applicable Control Point in sequence) and

$E_{E F L}=$ amount in the effluent waste stream (exiting the wastewater treatment or at applicable Control Point in sequence). 
Table 2

Performance indicators necessary for quantitative assessment of wastewater treatment and reuse.

\begin{tabular}{|c|c|c|c|c|}
\hline No & Performance indicator & Unit & Index target value & Value \\
\hline 1 & $\begin{array}{l}\text { Wastewater Reclamation Plant design } \\
\text { capacity }\end{array}$ & $\mathrm{kL} / \mathrm{d}$ & $\sum Q_{W R P D C}=100 \%$ & 2100 \\
\hline 2 & $\begin{array}{l}\text { Average wastewater feed to Wastewater } \\
\text { Reclamation Plant }\end{array}$ & kL/day & $Q_{W R P A C} / \mathrm{d}$ & 1690 \\
\hline 3 & $\begin{array}{l}\text { Average effluent production from } \\
\text { Wastewater Reclamation Plant }\end{array}$ & kL/day & $Q_{E N F} / \mathrm{d}$ & 1616 \\
\hline 4 & $\begin{array}{l}\text { Wastewater Reclamation Plant capacity } \\
\text { utilisation } Q W R P \text { expressed as a ratio } \\
\text { between design capacity } \Sigma Q_{W R P D C} \text { and } \\
\text { actual feed rate } \Sigma Q_{W R P A C}\end{array}$ & $\%$ & $Q_{W R P}=\frac{\sum Q_{W R P A C}}{\sum Q_{W R P D C}} \times 100 \%$ & 80 \\
\hline 5 & $\begin{array}{l}\text { Water Treatment Plant design capacity } \\
\Sigma Q_{W T P D C} \text { at Water Treatment Plant }\end{array}$ & $\mathrm{kL} / \mathrm{d}$ & $\sum Q_{W T P D C}=100 \%$ & 7500 \\
\hline 6 & $\begin{array}{l}\text { Average recycled water production } \\
Q_{\text {WTPAC }} \text { at Water Treatment Plant }\end{array}$ & kL/day & $Q_{W T P A C} / \mathrm{d}$ & 2097 \\
\hline 7 & $\begin{array}{l}\text { Water Treatment Plant capacity } \\
\text { utilisation expressed as a ratio between } \\
\text { design capacity } \Sigma Q_{W R P D C} \text { and average } \\
\text { production rate } Q_{W T P A C}\end{array}$ & $\%$ & $Q_{W T P}=\frac{\sum Q_{W T P A C}}{\sum Q_{W T P D C}} \times 100 \%$ & 28 \\
\hline 8 & $\begin{array}{l}\text { Peak recycled water production } Q_{W T P P P} \\
\text { at Water Treatment Plant }\end{array}$ & kL/day & $Q_{W T P P P} / \mathrm{d}$ & 6500 \\
\hline 9 & $\begin{array}{l}\text { Water Treatment Plant max. capacity } \\
\text { utilisation expressed as a ratio between } \\
\text { design capacity } \Sigma Q_{W R P D C} \text { and peak } \\
\text { production rate } Q_{W T P P P}\end{array}$ & $\%$ & $Q_{W R P}=\frac{\sum Q_{W T P P P}}{\sum Q_{W T P D C}} \times 100 \%$ & 88 \\
\hline 10 & $\begin{array}{l}\text { Stormwater usage volume } Q_{S W} \text { supplied } \\
\text { for treatment at Water Treatment Plant }\end{array}$ & kL/day & $Q_{S W}=$ Average yield & 500 \\
\hline 11 & $\begin{array}{l}\text { Daily mass of Total Solids generated by } \\
\text { activated sludge process at WRP }\end{array}$ & $\mathrm{kg} /$ day or & $P_{X, V S S}=Y_{o b s}(Q)\left(S_{0}-S\right) 1 \mathrm{~kg} / 10^{3} \mathrm{~g}$ & $\begin{array}{l}339 \text { or } \\
11.3\end{array}$ \\
\hline 12 & $\begin{array}{l}\text { Total electricity use in Water } \\
\text { Reclamation Plant }\end{array}$ & $\mathrm{kWh} / \mathrm{d}$ & $\sum E_{W R P}$ & 2090 \\
\hline 13 & $\begin{array}{l}\text { Average electricity use in Water } \\
\text { Reclamation Plant }\end{array}$ & $\mathrm{kWh} / \mathrm{kL}$ & $I_{W R P}=\frac{E}{Q}$ & 1.6 \\
\hline 14 & $\begin{array}{l}\text { Total electricity use in Water Treatment } \\
\text { Plant (MF, RO, disinfection \& pumps }\end{array}$ & $\mathrm{kWh}$ & $\sum E_{W T P}$ & 80,050 \\
\hline 15 & $\begin{array}{l}\text { Average electricity use in Water } \\
\text { Treatment Plant (MF, RO, } \\
\text { disinfection \& pumps }\end{array}$ & $\mathrm{kWh} / \mathrm{kL}$ & $I_{W T P}=\frac{E}{Q}$ & 1.5 \\
\hline 16 & $\begin{array}{l}\text { GHG emission resulting from WRP } \\
\text { and WTP calculated per unit volume } \\
\text { (NSW coef. } 1 \mathrm{kWh}=0.98 \mathrm{~kg} \text { ) }\end{array}$ & $\mathrm{kgCO} 2 / \mathrm{kL}$ & $\sum G H G=\left(I_{W R P}+I_{W T P}\right) \times 0.98$ & 1.52 \\
\hline 17 & $\begin{array}{l}\text { Total quantity of disinfection chemicals } \\
\text { used at Water Treatment Plant }\end{array}$ & $\mathrm{g} / \mathrm{KL}$ & $\sum M_{\text {chem }} / \mathrm{kL}$ & 7.30 \\
\hline 18 & $\begin{array}{l}\text { Total annual potable water saving by } \\
\text { WRAMS }\end{array}$ & $\mathrm{kL} / \mathrm{y}$ & $Q_{\text {WTPAC }}$ & 765,405 \\
\hline
\end{tabular}

There is a limited research activity in the areas of measuring efficiency and productivity of wastewater reuse mainly due to unavailability of operational data and the lack of suitable performance indicators. Efficiency instruments could apply to the entire treatment process or to an individual component eg. technical efficiency of microfiltration process.

In the input orientation the efficiency scores relate to the largest feasible proportional reduction in inputs for fixed outputs, while in the output orientation it 
Table 3

Performance indicators necessary for qualitative assessment of wastewater treatment and reuse process.

\begin{tabular}{llll}
\hline No & Performance indicator index & Unit & Index target value \\
\hline 1 & BOD5 load entering treatment & $\mathrm{kg}$ & $\mathrm{kg} / \mathrm{kL}$ \\
2 & COD load entering treatment & $\mathrm{kg}$ & $\mathrm{kg} / \mathrm{kL}$ \\
3 & Total Nitrogen (TN) entering treatment & $\mathrm{kg}$ & $\mathrm{kg} / \mathrm{kL}$ \\
4 & Total Phosphorous (TP) entering treatment & $\mathrm{kg}$ & $\mathrm{kg} / \mathrm{kL}$ \\
5 & Total Solids (TS) entering treatment & $\mathrm{kg}$ & $\mathrm{kg} / \mathrm{kL}$ \\
6 & Total Suspended Solids (TSS) entering treatment & $\mathrm{kg}$ & $\mathrm{kg} / \mathrm{kL}$ \\
7 & Total Pollutants load entering treatment & $\mathrm{kg}$ & $\mathrm{kg} / \mathrm{kL}$ \\
8 & BOD5 load entering treatment & $\mathrm{kg}$ & $\mathrm{kg} / \mathrm{EP}$ \\
9 & COD load entering treatment (EP) & $\mathrm{kg}$ & $\mathrm{kg} / \mathrm{EP}$ \\
10 & Total Nitrogen (TN) entering treatment $(\mathrm{EP})$ & $\mathrm{kg}$ & $\mathrm{kg} / \mathrm{EP}$ \\
11 & Total Phosphorous (TP) entering treatment $(\mathrm{EP})$ & $\mathrm{kg}$ & $\mathrm{kg} / \mathrm{EP}$ \\
12 & Total Solids (TS) entering treatment (EP) & $\mathrm{kg}$ & $\mathrm{kg} / \mathrm{EP}$ \\
13 & Total Suspended Solids (TSS) entering treatment $(\mathrm{EP})$ & $\mathrm{kg}$ & $\mathrm{kg} / \mathrm{EP}$ \\
14 & Total Pollutants load entering treatment per EP & $\mathrm{kg} / \mathrm{EP}$ \\
15 & Biosolids production in wastewater treatment kg/kL/day & $\mathrm{kg} / \mathrm{kL}$ \\
16 & BOD5 load removed in treatment kg/kL/day & $\mathrm{kg}$ & $\mathrm{kg} / \mathrm{kL}$ \\
17 & COD load removed in treatment $\mathrm{kg} / \mathrm{kL} /$ day & $\mathrm{kg}$ & $\mathrm{kg} / \mathrm{kL}$ \\
18 & Total Nitrogen (TN) removed in treatment $\mathrm{kg} / \mathrm{kL} / \mathrm{day}$ & $\mathrm{kg} / \mathrm{kL}$ \\
19 & Total Phosphorous (TP) removed in treatment $\mathrm{kg} / \mathrm{kL} / \mathrm{day}$ & $\mathrm{kg}$ & $\mathrm{kg} / \mathrm{kL}$ \\
20 & Total Solids (TS) removed in treatment kg/kL/day & $\mathrm{kg}$ & $\mathrm{kg} / \mathrm{kL}$ \\
21 & Total Suspended Solids (TSS) removed in treatment & $\mathrm{kg} / \mathrm{kL}$ \\
22 & Total Pollutants load removed in treatment & $\mathrm{kg} / \mathrm{kL}$
\end{tabular}

Table 4

Microfiltration efficiency-pollutants removal (WRAMS).

\begin{tabular}{lllll}
\hline Parameter & Unit & $\begin{array}{l}\text { CMF feed }- \\
\text { (weekly } \\
\text { average) }\end{array}$ & $\begin{array}{l}\text { Cmf filtrate } \\
\text { (weekly average) }\end{array}$ & $\begin{array}{l}\text { MF removal efficiency index } \\
\text { (CMF) }\end{array}$ \\
\hline Biological oxygen demand & $\mathrm{mg} / \mathrm{L}$ & 5 & 1.3 & 74 \\
Chemical oxygen emand & $\mathrm{mg} / \mathrm{L}$ & 35 & 10 & 60 \\
Total dissolved solids & $\mathrm{mg} / \mathrm{L}$ & 660 & 660 & 2 \\
Suspended solids & $\mathrm{mg} / \mathrm{L}$ & $<2$ & $<2$ & 87 \\
True colour & $\mathrm{Pt}-\mathrm{Co}$ & 27 & 9 & 67 \\
pH & $\mathrm{pH}$ & 7.7 & 7.6 & 69 \\
Turbidity & $\mathrm{NTU}$ & 6.5 & 2 & 75 \\
Total oil and grease & $\mathrm{mg} / \mathrm{L}$ & 2 & 0.5 & 58 \\
Ammonia (as N) & $\mathrm{mg} / \mathrm{L} \mathrm{N}$ & 1.9 & 0.8 & 36 \\
Total oxidised nitrogen & $\mathrm{mg} / \mathrm{L} \mathrm{N}$ & 1.1 & 0.7 & 2.3 \\
Total Kjel. nitrogen (calc) & $\mathrm{mg} / \mathrm{L} \mathrm{N}$ & 3 & 2.3 & 32 \\
Total nitrogen & $\mathrm{mg} / \mathrm{L} \mathrm{N}$ & 4.1 & 2.8 & 33 \\
Total phosp (as P) & $\mathrm{mg} / \mathrm{L} \mathrm{P}$ & 1.2 & 0.45 & 2.3 \\
\hline
\end{tabular}

corresponds to the largest feasible proportional expansion in outputs for fixed inputs [12].

\subsection{WRAMS—productivity assessment}

The process productivity could be measured by the following alternative methods:

- Volume of flow that can pass through a unit area of membrane surface and is commonly referred to as the "flux rate".
- Removal of particulate contaminants from a feed stream by separation based on retention of contaminants on a membrane surface.

In case of microfiltration MF, productivity assessment could be also calculated by evaluating decline in flux over time. Flux rates are typically measured in units of litres of flow per square meter of membrane per hour $\left(\mathrm{L} / \mathrm{m}^{2} / \mathrm{h}\right)$. Typical values for microfiltration membranes range from 25 to 50 , or more, depending upon the 
amount of solids and chemical composition of the feed streams. The productivity index of MF represents the volume of product water obtained from the total mass of influent and it could be calculated using the following equation (Tables 5 and 6):

$$
P_{I}=\frac{\text { Output }}{\text { Input }}
$$

\subsection{WRAMS-reliability assessment}

Evaluating the reliability of treatment processes and its products is an important part of the planning and design process for water resource, wastewater treatment, and particularly wastewater reuse projects. Consequently an appropriate reliability tools and the performance standards need to be developed, to enable analysis of the system/process performance and whether the system/process are meeting those standards and what reliability level would be required [13].

Most important reliability features at WRAMS include:

- source quality control,

- use of safety factors in process design

- statistical analysis of treatment plant performance

- necessary standby and redundancy provisions

- monitoring devices and automatic controllers

- multi-barrier treatment processes arranged sequentially

- provisions for adequate and reliable disinfection

The process of reliability assessment, called Component Reliability Evaluation (CRE) relies on selection of typical parameters, range and variability of measurements and operational records (observation) that characterise treatment technology. The key elements include the following:

- flow rates

- total suspended solids (TSS),

- biochemical oxygen demand (BOD5),

- chemical oxygen demand (COD),

- total nitrogen (TN),

- total phosphorus (TP)

- virus, pathogens, faecal or thermotolerant coliforms (FC) present in treated recycled water by applying several statistical tests

- virus and pathogens

- mechanical, electrical and automation system performance

The process of determination of a particular reliability value involves use of individual or combined reliability indexes.

Table 5

MF microfiltration volume productivity index.

\begin{tabular}{lll}
\hline $\begin{array}{l}\text { Total inflow } \\
(\mathrm{kL} / \mathrm{d})\end{array}$ & $\begin{array}{l}\text { Filtrate } \\
(\mathrm{kL} / \mathrm{d})\end{array}$ & $\begin{array}{l}\text { Productivity } \\
\text { index }(\mathrm{PI})\end{array}$ \\
\hline 1915 & 1601 & 79.3 \\
3229 & 2738 & 81.2 \\
3205 & 2746 & 82 \\
1905 & 1681 & 76.5 \\
2084 & 1681 & 75.3 \\
2271 & 1948 & 81.3 \\
2127 & 1971 & 82.5 \\
2235 & 1938 & 81.3 \\
\hline
\end{tabular}

Table 6

MF microfiltration quality productivity index.

\begin{tabular}{|c|c|c|c|c|c|c|}
\hline \multirow[t]{2}{*}{ Parameter } & \multirow[t]{2}{*}{ Unit } & \multicolumn{2}{|c|}{ Concentration } & \multirow{2}{*}{$\begin{array}{l}\text { Quality } \\
\text { productivity } \\
\text { index }(\%)\end{array}$} & \multirow{2}{*}{$\begin{array}{l}\text { Limit target } \\
\text { applied }\end{array}$} & \multirow{2}{*}{$\begin{array}{l}\text { Percentage of } \\
\text { limit index }\end{array}$} \\
\hline & & Feed water & Filtrate & & & \\
\hline BOD5 & $\mathrm{mg} / \mathrm{L}$ & 5 & 1.3 & 74 & $<2$ & 65 \\
\hline COD & $\mathrm{mg} / \mathrm{L}$ & 35 & 10 & 57 & 10 & 100 \\
\hline Ammonia & $\mathrm{mg} / \mathrm{L}$ & 3.8 & 0.8 & 78 & 2 & 40 \\
\hline Total nitrogen $(\mathrm{TN})$ & $\mathrm{mg} / \mathrm{L}$ & 4.1 & 3.2 & 22 & 12 & 27 \\
\hline Total phosphorous (TP) & $\mathrm{mg} / \mathrm{L}$ & 0.79 & 0.54 & 32 & 1 & 54 \\
\hline Total suspended solids (TSS) & $\mathrm{mg} / \mathrm{L}$ & $<2$ & 0 & 100 & 0 & 100 \\
\hline Total dissolved solids (TDS) & $\mathrm{mg} / \mathrm{L}$ & 660 & 600 & 9 & 500 & 100 \\
\hline $\mathrm{pH}$ & $\mathrm{mg} / \mathrm{L}$ & 7.7 & 7.7 & 0 & $6.5-8.5$ & na \\
\hline Turbidity & NTU & 6.5 & $<1$ & 99 & $<2$ & $<50$ \\
\hline FC (CFU/100 mL) & no & 1700 & $<1$ & 100 & $<1$ & 100 \\
\hline
\end{tabular}




\section{Conclusion}

Assessment methodology outlined above represents in-depth analysis of the treatment process performance, operational conditions, efficiency of the system, while the classical technology due diligence procedure is generally designed to ascertain the economic values and results of operations and express them in financial terms. It is an interactive and communicative process with the aim to contribute to the public and political opinion forming on science and technology related societal aspects [10] like exploitation of potential effects and technological risks, overcoming problems of legitimacy and technology conflicts.

It produces knowledge, orientation and procedures to deal with societal challenges in coping with technology. Over the last years, the landscape for assessment methodologies has significantly changed. It started with the single engineering/technical feasibility appraisal, and progressively expanded to a wider context involving many components and issues. The development of an integrated assessment framework is regarded as a positive step in the process of providing a balanced approach, the opportunity to formulate more informed public opinions, effective interpretation of the complex scientific and technical terms to more widely understandable format and effective transition from the speculations, guesswork, perceptions through facts to public acceptance.

Uniform performance methodology will help to capture the complexity associated with the wastewater treatment and reuse technology, yet it remains understandable and amenable for rational discussion, helping in selection and decisions making process.

Selection of assessment criteria and performance indicators is reflecting of a number of objectives, motives, values, philosophies and principles that have been combined into the following main themes:

- maximising use of technology

- maximising performance

- minimising use of resources

Initial case study identified a number of issues that would need to be considered in future research including:

- Data collection regime, accuracy and relevance continue to be insufficient. This is due to minimalistic approach to use resources

- More focus on benefit analysis would enable more comprehensive decision making process, particularly when choosing between various technologies

- Recommended continued development of a life/ use cycle analytical methodology could provide useful tool for designers and operators of treatment technology
- Creation of aggregated performance index for each performance criterion could simplify assessment process and could allow better comparison between different reuse schemes.

\section{Acknowledgments}

This study was supported by Australian Research Council (ARC) Industry Linkage Grant (LP0882089).

\section{References}

[1] PMSEIC, Recycling Water For Our Cities, Prime Minister's Science, Engineering and Innovation Council, November 2003.

[2] T. Fleischer and A. Grunwald, Technikgestaltung für mehr Nachhaltigkeit-Anforderungen an die Technikfolgenabschätzung." In. A. Grunwald (Hg.):Technikgestaltung für eine nachhaltige Entwicklung-Von der Konzeption zur Umsetzung, Edition Sigma, Berlin, 2002.

[3] C. Krotscheck and M. Narodoslawsky, The Sustainable Process Index-A new dimension in ecological evaluation, Ecol. Eng., 6(4) (1996) 241-258

[4] F. Hernández, A. Urkiaga, L. De las Fuentes, B. Bis, E. Chiru, B. Balazs and T. Wintgens, Feasibility studies for water reuse projects: An economical approach, Desalination, 187 (2006) 253-261.

[5] M. Po, J. Kaercher and B.E. Nancarrow, Literature review of factors influencing public perceptions of water reuse, Australian Water Conservation and Reuse Research Program www. clw.csiro.au/publications/technical2003/tr54-03.pdf, Access date 6/1/05, 2004.

[6] G.J. Syme and B.S. Sadler, Evaluation of public involvement in water resources planning. A researcher-practitioner dialogue, Evaluation Review, 18(5) (1994) 523-542.

[7] J.A. Bellamy, G.T. McDonald, G.J. Syme and J.E. Butterworth, Evaluating integrated resource management. Society and Natural Resources, 12 (1999) 337-353.

[8] J.A. Bellamy, D.H. Walker, G.T. McDonald and G.J. Syme, Syme, A systems approach to the evaluation of natural resource management initiatives, J. Environmental Management, 63 (2001) 407-423.

[9] C. Fabricius, R.J. Scholes and G. Cundill, Mobilising knowledge for ecosystem assessments. Paper presented at Bridging Scales and Epistemologies: Linking Local Knowledge and Global Science in Multi-Scale Assessments, March. Alexandria, Egypt, 2004

[10] D. Bütschi, R. Carius, M. Decker, S. Gram, A. Grunwald, P. Machleidt, S. Steyaert and R. van Est, "The Practice of TA. Science, Interaction, and Communication." In: M. Decker, M. Ladikas (Eds.): Bridges between Science, Society and Policy. Technology Assessment - Methods and Impacts. Springer Heidelberg, New York, 2004.

[11] T.J. Coelli, A. Estache, S. Perelman and L. Trujillo, A Primer on Efficiency Measurement for Utilities and Transport Regulators, World Bank Institute, Washington D.C., 2003.

[12] Eco Eng-Newsletter No. 11, October 2005, 6-8. 